УДК 780.647.2.0712:78.03(477.54-25)

ORCID 0000-0002-4134-4403

\title{
Стрілець Андрій
}

Харківський національний університет мистецтв

ім. І. П. Котляревського

\section{ХАРКІВСЬКА РЕГІОНАЛЬНА ШКОЛА ГРИ НА БАЯНІ (АКОРДЕОНІ): ІСТОРІЯ, ВИКОНАВСЬКІ ПРИОРІТЕТИ}

Стрілець А. Харківська регіональна школа гри на баяні (акордеоні): історія, виконавські приорітети, персоналії. Статтю присвячено обгрунтуванню ролі баяна (акордеону) в сучасному соціокультурному просторі музичного мистецтва України на прикладі однієї з провідних шкіл, створеної на базі Харківського державного інституту мистецтв ім. І. П. Котляревського в 1951 році. Надано аналіз Харківської регіональної баянної школи (від другої половини XX ст. до нині); розкрито ії персоналії на грунті вивчення п'яти генерацій виконавців-викладачів. Узагальнено чинники, які впливають на невпинність змін в усталених традиціях регіональної школи гри на баяні. Позначається тенденція до певної уніфікації виконавців відповідно до стилістичних напрямків музичного мистецтва, які вони обрали для творчого самовираження. Окреслено перспективи розвитку харківської виконавської школи в світі сучасних технологій і необмежених кордонів музичної комунікації.

Ключові слова: баян, Харків, регіональна школа, генерація виконавціввикладачів.

Стрелец Андрей. Харьковская региональная школа игры на баяне (аккордеоне): история, исполнительские приоритеты, персоналии. Статья посвящена обоснованию роли баяна (аккордеона) в современном социокультурном пространстве музыкального искусства Украины на примере одной из ведущих школ, созданной на базе Харьковского государственного института искусств им. И. П. Котляревского в 1951 году. Представлен анализ Харьковской региональной баянной школы (от второй половины XX века и до ныне); названы её представители на основе изучения пяти генераций исполнителей-педагогов. Обобщены факторы, обуславливающие постоянство процесса изменений в сложившихся традициях региональной школы игры на баяне. Обозначена тенденция к унификации исполнителей в соответствии со 
стилистическими направлениями искусства, выбранными ими для творческого самовыражения. Обозначены перспективы развития харьковской исполнительской школы в мире современных технологий и неограниченных возможностей музыкальной коммуникации.

Ключевые слова: баян, Харьков, региональная школа, генерация, исполнители-педагоги.

\section{Strilets Andriy. «Kharkiv regional school of chromatic button accordion playing: the history, the personalities and the priorities of performing».}

Background. The article focuses on articulating the role of chromatic button accordion in the modern sociocultural system of Ukrainian musical art, based on the case of one leading school established in 1951 on the basis of Kharkiv National Kotlyarevskyj University of Arts.

Objectives. The objective of the article is to provide an analysis of Kharkiv regional accordion school (since the second half of the 20th century to the present day), as well as its personalities using as an example five generations of performersteachers.

Methodology of the study includes researching of the history and practice of performing chromatic button accordion (the fundamental works of M. Imkhanycjkyj, U. Loshkova, I. Snjedkov, A. Mirek, A. Stashevskyj)

Results. After the invention of the chromatic button accordion a little over 100 years ago, it went from a primitive musical instrument satisfying everyday needs to one recognized on the professional concert stage. The status of the instrument has been changing hand in hand with its improvement and the creation of original repertoire. Now the chromatic button accordion is on par with other academic instruments recognized worldwide.

Currently there are four chromatic button accordion schools in Ukraine - in Kyiv, Odessa, Lviv and Kharkiv. Kharkiv has been viewed as a regional center of development of the chromatic button accordion performing since early 20-ies of the 20th century. However, the original "Kharkiv school of performing" was fully established with the opening of the chromatic button accordion class at the orchestra department of the University in 1951. This event became final in the formation of the system of professional chromatic button accordionists and teachers preparation. It is as follows: music school, music college, conservatory. The founder of the chromatic button accordion class was L. M. Horenko (19251989). Volodymyr Yakovych Podgornyj (1928-2010), an outstanding performer, composer and teacher, played the key role in the formation of Kharkiv original chromatic button accordion school. His unique compositional and performing style dramatically changed the teaching methodology, performance priorities, 
approaches to transcription and translation of works for an chromatic button accordion, the "harmonic mindset". Volodymyr Yakovych contributed greatly to the creation of original chromatic button accordion repertoire which surpassed existing samples in its quality, giving a new direction to the chromatic button accordion development not only in Kharkiv, Ukraine but also abroad. Thus, L. M. Horenko and V. Y. Podgornyj became the first generation of chromatic button accordion teachers in Kharkiv National Kotlyarevskyj University of Arts.

The second generation of teachers at the department including Podgornyj's students O. I. Nasarenko and A. P. Ghaidenko used to uphold these principles, but they also brought additional details generally related to their inherent features of character. The representatives of the third generation at the department professors O. V. Mishhenko and I. I. Snjedkov brought innovative characteristics to the general terms of the performing school. They have been known to pay attention to the logic of dramatic development, conciseness of musical forms, technical perfection, academicism, the balance of the emotional and rational performance components, the perfection of small intonation pieces.

The fourth generation includes Andrij Ghetman who'd been working since 1995 to 2007, and Andrij Strilets who started his career in 1998. They both were students of Kharkiv chromatic button accordion school taught by Professor I. I. Snjedkov. Following general principles of "Podgornyj school", those personalities deviate significantly from the original source. A. Ghetman's performing is characterized by specific academicism both in the quality of performing and in selecting a concert repertoire. A. Strilets distinguishes by advanced orchestral thinking, focused work with the viewer, attention to a musical phrase structure, expressiveness and emotional completeness of performance.

The fifth generation consists of Dmytro Zharikov (a soloist of the regional Philharmonic society) who has received a Master's degree at Rostov Academy of Music named after. S. V. Rakhmaninov under the direction of the world-famous accordion player Yurij Shyshkin and Yurij Djjachenko (a student of O. I. Nasarenko) who teaches the conducting course. They have worked at the department since 2015.

Conclusion. The modern chromatic button accordion through developing in the plane of professional instrumental performing, repeats the path of other famous academic musical instruments. Moreover, Kharkiv regional accordion school, being one of the leading development centers of the chromatic button accordion in Ukraine, has entered the value system of the 21 st century culture. Its development and increasing authority in the world arena are related to: 1) the further integration into the extensive network of European music universities; 2) experience exchange not only at the level of teaching methods, but also through 
the introduction of exchange programs with students from leading conservatories of different countries worldwide; 3 ) the creation of the conditions for the training of a certain unification specialists according to the existing genre and stylistic directions of performance on chromatic button accordion; 4) the orientation on the implementation of all the advanced instruments constructive capabilities (sound production and strokes) and timbral coloring; 5) the search for forms of the chromatic button accordion (as an academic instrument) creative synthesis: from established forms of ensembles (such as strings or wind) to modern theatrical, vocal and dance performances, music and light show.

Keywords: bayan, Kharkov, regional school, generation, performers, teachers.

Постановка проблеми. Баян - інструмент достатньо молодий. Вік перших дуже спрощених за конструкцією зразків налічує менше ніж 200 років, більш подібних хроматичних - трохи біля 100 років, а готово-виборному багато тембровому інструменту сучасного зразка - лише близько 50 років. За цей час баян пройшов довгий шлях від примітивного музичного інструменту для задоволення певних побутових потреб до визнання на професійній концертній естраді. Зміни у статусі інструмента відбувалися паралельно з його удосконаленням та створенням оригінального репертуару. I зараз баян (акордеон) стоїть на одному щаблі з іншими, визнаними у всьому світі, академічними музичними інструментами. Таке твердження $є$ вірним i на глобальному рівні. Інструменти ідентичні або дуже схожі за конструкцією до нашого українського концертного баяну побутують на всіх континентах. Доречно згадати думку А. Мірека щодо етнічної приналежності того чи іншого інструменту: «....не имеет никакого значения то, в какой стране, у какого народа впервые появилась первоначальная конструкция того или иного инструмента для выявления его национальной принадлежности. Основополагающий критерий - именно традиционность бытования в определённой этнической среде для выражения национального музыкального искусства» [3, с. 486]. У розвиток цього судження, слід зазначити, що воно є вірним стосовно пневматично-язичкових інструментів (подібних до баяну за конструкцією), які побутують в інших країнах світу. Актуальність теми складає необхідність розгляду сучасного стану розвитку мистецтва гри на цьому інструменті, який належить 
культурі глобалізованого світу.

Мета дослідження - надати аналіз харківської регіональної баянної школи від генези (другої половини ХХ ст.) до сьогодення.

Виклад основного матеріалу. Шлях до визнання баяну як академічного інструменту проходив через створення оригінального репертуару. А. Сташевський так пише на цю тему: «Наявність саме власного репертуару, з одного боку, та відповідність його якіснопрофесійного та художньо-естетичного рівня нормам репертуару камерно-інструментальних жанрів - 3 іншого, посідає значне місце на шляху академізації будь-якої музично-інструментальної культури» [8, с. 119]. Поява нових творів для баяна всесвітньовідомих композиторів (К. Пендерецький, С. Губайдуліна, М. Кегель) засвідчила перспективність інструменту. Нині кількість оригінального репертуару для баяна і його жанрове розмаїття настільки велике, що дозволяє майже повністю відмовитись від запозичень, як в навчальному процесі, так в концертній практиці.

Потужним чинником визнання баяна як інструмента глобального значення стала діяльність всесвітньо відомих композиторів-виконавців Астора П'яццоли (бандонеон) та Рішара Гальяно (кнопковий акордеон - аналог сучасного баяну). Популярність їх мелосу і ритмів, стовідсоткова відповідність запитам суспільства має загальнооб'єднуюче значення. Виконання творів П'яццоли і Гальяно ансамблями різного складу із залученням інструментів симфонічного оркестру надало поштовх для пошуку нових тембральних мікстів за участю баяна, ствердженню баяна у складі ансамблів за участю струнно-смичкових, дерев'яних духових інструментів, фортепіано та ударних інструментів. За короткий проміжок часу склад таких ансамблів ствердився, як сталий. 3'явився певний стилістичний напрямок «П'яццола ансамблі». Інтерес до таких колективів не вщухає по всьому світі. Концертні твори для баяна і симфонічного оркестру ще більше зміцнили позиції інструмента, як концертного і академічного. Тому сприйняття сучасного баяна як «народного» інструмента вважається сумнівним. По-перше, через загальносвітове розповсюдження не можливо визначити, якому саме народу він належить. По-друге, на сучасному етапі розвитку він має всі ознаки академічного інструменту. Отже, сучасне баянне мистецтво є явищем 
глобального значення, тому що сприймається всією світовою музичною спільнотою, як стале, сформоване і пізнаване.

Нині в Україні діють чотири регіональні баянні школи: київська, одеська, львівська, харківська. (П'ята школа - донецька, з відомих причин втратила свої позиції).

Харків, як регіональний центр розвитку академічного виконавства на баяні, відомий ще 3 початку 20 -х років XX ст. Перший в Україні клас народних інструментів відкрито 1920 року у музичній Профшколі №2 Володимиром Андрійовичем Комаренком, а вже через рік професійне навчання здійснювалося в шести профшколах. 1927 року в Харкові було проведено Перший всеукраїнський конкурс гармоністів. У 1934 р. клас баяна відкрито у Харківському музичному училищі, а у 1943 - у спеціалізованій дитячій музичній школі. Але повноцінне формування оригінальної «харківської школи гри» почалося 3 відкриттям класу баяна при оркестровій кафедрі Харківської консерваторії в 1951 році, який і став верхівкою сформованої ланки підготовки професійних кадрів - виконавців на баяні і викладачів. Засновником класу баяна став Л. М. Горенко (1925-1989), який на той час працював солістом Харківського обласного радіо та був завзятим популяризатором баяна. В роботі зі студентами професор Л. М. Горенко активно займався вирішенням проблеми виконавського репертуару. Ним зроблено близько 50 обробок і перекладень для баяна відомих фортепіанних і скрипкових творів. Леонід Миронович підготував десятки високопрофесійних музикантів, серед яких доктор мистецтвознавства, академік Російської академії музики імені Гнесіних М. Й. Імханицький, професор Харківської державної академії культури Т. В. Большакова, доценти В. Курисько і О. Чиняков.

М. А. Давидов виокремлює харківську школу гри на баяні в своєму підручнику «Історія виконавства на народних інструментах», зазначаючи наступне: «...1ї потужне історичне минуле i композиторський потенціал» [1, с. 5]. І це висловлювання перш за все пов'язано з постаттю видатного митця і композитора - Володимира Яковича Подгорного (1928-2010). Саме його неповторний композиторський і виконавський стиль, починаючи з другої половини 50-х - початку 60-х років минулого століття, назавжди змінив методику викладання гри на інструменті, виконавські приорітети, підходи до 
транскрипції та перекладень творів для баяна, «гармонічне мислення» і культуру звуковидобування баяністів Харкова. 1956 року після закінчення композиторського відділення (клас В. Т. Борисова) та відділення народних інструментів Володимир Якович стає викладачем Харківської консерваторії. Подгорний мав величезний авторитет серед студентів, а його несамовито експресивне і надзвичайно чуттєве виконання творів вихором підкорювало серця слухачів і учнів. Потужна складна гармонія, симфонізація і поліфонізація фактури приголомшували. В. Я. Подгорний створив новий вектор розвитку баяна не тільки для Харкова і України, а й для баянного мистецтва всього СРСР. Не дарма В. Подгорний був прийнятий до лав союзу композиторів СРСР вже через два роки після закінчення консерваторії. Володимир Якович плідно працював над збільшенням виконавського репертуару баяністів. Йому належить близько 30 неповторних і вишуканих творів для баяна, «Альбом для юнацтва», «Школа технічної майстерності і ладо-гармонічного мислення», велика кількість перекладень і транскрипцій для баяна фортепіанної, скрипкової та оркестрової музики відомих авторів, музика для домри, вокальна музика і музика для симфонічного оркестру.

Володимир Якович - людина незряча з покаліченою кистю правої руки силою таланта, труда і непереборного бажання до навчання зміг екстерном закінчити музичне училище, композиторське відділення Харківської консерваторії і паралельно за два роки виконавське відділення кафедри народних інструментів. Тим самим вказавши шлях іншим молодим талановитим музикантам. І вони наслідували приклад «вчителя». Навчання на кількох факультетах консерваторії саме серед «народників» Харкова стає нормою, так же, як і великий відсоток композиторів серед викладачів кафедри народних інструментів. Ця своєрідна риса, як візитівка, зберігається і по сьогоднішній день, вирізняючи Харківську регіональну школу виконавців на народних інструментах від інших музичних навчальних центрів України. Серед учнів Володимира Яковича - заслужені діячі мистецтв України, професори О. Назаренко, А. Гайденко, В. Овод, заслужений артист України О. Міщенко, лауреати міжнародних і національних конкурсів Ю. Абраменко, В. Зеленюк, П. Потапов, Є. Малихін, Ю. Свенко та ін. Як пише у навчальному посібнику I. Снєдков: «досягнення 
Володимира Яковича в педагогіці більшою мірою обумовлені його композиторським досвідом і виконавським талантом. Відомо, який вплив на учня має педагог, який сам блискуче володіє інструментом...». Бажання учня досягти такого ж рівня майстерності підбурює його до ще більш наполегливої праці. Володимир Якович цінував час проведений в колі однодумців. Постійне спільне обговорення репертуару, концертів, поїздок на конкурси, перші виконання творів перед студентами і колегами працювали на духовне наближення і формування оригінального виконавського стилю. Головною рисою якого було акцентування уваги на художньому образі. Велике значення мала робота Подгорного 3 впровадження п’ятипальцевої аплікатури, розвитку ладо-гармонічного мислення студентів, розробки нових виконавських прийомів, створення ансамблів і концертного репертуару для них. Додам кілька слів про винятковий слух і музичну пам'ять Подгорного, який був здатен почути найменшу фальш в будь-якій насиченій фактурі з великої відстані та одразу сповіщав про це, що спонукало студентів до максимально ретельного відношення до тексту. Отже, В. Я. Подгорний і Л. М. Горенко стали першою «zенерацією» викладачів по класу баяна Харківської консерваторії.

Однак будь-яка виконавська школа, що грунтується на надбаннях певної особистості (в даному випадку В. Я. Подгорного) і його найближчих однодумців та учнів, не може історично довго знаходитися в незмінних межах сталих принципів і вироблених положень (догм). Вплив часу, поява нових особистостей, широке коло спілкування, а тим більш вплив сучасного необмеженого інтернет та медіа простору, спонукають до неминучих змін навіть у дуже замкненому середовищі. I якщо друга «генерація» викладачів кафедри - О. І. Назаренко, А. П. Гайденко, що находились під впливом школи Подгорного, повністю сповідували його принципи, в цілому були його однодумцями і привносили деталі, які пов'язані більшою мірою 3 певними рисами їх особистості.

Слід зазначити, що обидва професори кафедри є яскравими творчими діячами. В творчому доробку заслуженого діяча мистецтв України, професора Назаренка О. I. (1938 р.н.) є десятки музичних творів для баяна соло і оркестру баянів, перекладень і обробок для 
ансамблів баяністів, аранжувань і транскрипцій, наукових робіт, публікацій, записів на радіо і телебаченні. Олександр Іванович за час свого творчого шляху був керівником і диригентом великої кількості оркестрів баяністів серед яких і оркестр баяністів ХНУМ ім. І. П. Котляревського. Впродовж 10 років займав посаду декана оркестрового факультету. О. I. Назаренко $\epsilon$ невтомним продовжувачем традицій Харківської школи виконавства на баяні. Його вирізняє вишукана манера звуковидобування, імітація і пошук нових тембрів на баяні, велика увага до насиченості та багатошаровості баянної фактури, рельєфності фактурних планів та витонченої гармонії.

Заслужений діяч мистецтв України, професор А. П. Гайденко (1937 р.н.) - людина 3 дуже грунтовною музичною освітою (виконавець, композитор, теоретик). Він $є$ автором близько 100 абсолютно різнопланових музичних творів для симфонічного оркестру, хору, оркестру народних інструментів, ансамблів різноманітного складу, солістів інструменталістів і вокалістів. Має численні записи власних творів в Фонді Радіокомпанії України та успішно співпрацює з ведучими колективами і виконавцями нашої держави. Професор має дуже широке коло інтересів і знань, якими ділиться зі своїми учнями, впроваджуючи виконавський і педагогічний досвід «харківської школи» гри на баяні. Анатолій Павлович є знавцем пісенної і інструментальної музичної традиції не тільки українського народу, а й багатьох народів, що мешкають на європейському просторі. Він сповідує принципи поміркованого концертного стилю, одночасно спираючись на академізм і традицію народного музикування, віртуозність та значну увагу до метро-ритмічної структури музики.

Tретя «zенерація» викладачів кафедри - професори Міщенко О. В. та Снєдков I. I. - починає привносити нові риси до загальних положень виконавської школи. Кілька слів про цих видатних музичних діячів Харківщини.

I. І. Снєдков (1954 р.н.) вихованець класу М. В. Чекмарьова (19281998) (однодумця В. Я. Подгорного), заслужений діяч мистецтв України, професор, лауреат міжнародних конкурсів, концертний виконавець, ансамбліст, досвідчений викладач, організатор і художній керівник численних концертних народно-інструментальних колективів. 
О. В. Міщенко (1956-2018) - учень В. Я. Подгорного, заслужений артист України, лауреат міжнародних конкурсів, професор, концертний виконавець, ансамбліст, відомий викладач, автор великої кількості навчальних посібників і публікацій з приводу теорії та практики виконавства на баяні. Обидва музиканта завершували навчання в асистентурі-стажуванні ДМПІ ім. Гнєсіних (м. Москва) у складі дуету під керуванням доктора мистецтвознавства, професора М. Й. Імханіцького (до речі, теж вихованця Харківської школи клас Л. М. Горенка), і це беззаперечно вплинуло на їх музичний світогляд. Тим більше, що як говорить I. I. Снєдков: «... ми з Олександром Володимировичем напрошувались на консультації до всіх провідних викладачів вишу і не тільки народників, складаючи певну статистику висловлених думок і побажань. У такий спосіб намагались подолати суб' єктивізм, наближаючись до об'єктивного судження». Отже, вже третя генерація викладачів усвідомила найкращі надбання московської баянної школи, певним чином інтерпретувала їх та почала втілювати в свою подальшу виконавську і педагогічну діяльність. Серед нових рис, що додались до сталих принципів «школи Подгорного», - велика увага до логіки драматургічного розвитку, зрозумілість і лаконізм музичної форми в цілому, технічна досконалість, академізм, пошук рівноваги у співвідношенні емоційного і раціонального планів, ретельність відпрацювання дрібних інтонаційних побудов.

До четвертої «генерації» викладачів кафедри належать Андрій Гетьман (1971 р.н. працював з 1995 по 2007 рік) та Андрій Стрілець (1974 р.н. працює з 1998 року). Обидва вихованці харківської баянної школи, клас заслуженого діяча мистецтв України, професора I. I. Снєдкова, є лауреатами і переможцями численних міжнародних i національних конкурсів. Сповідуючи загальні принципи «школи Подгорного», ці персоналії в своїй роботі вже помітно відхиляються від першоджерела. А. А. Гетьман, яскравий виконавець, соліст і відомий ансамбліст (у складі дуету з Дмитром Шаршонєм), є продовжувачем традицій Харківської школи. Його манера виокремлювалась особливим академізмом, як в площині довершеної якості виконання музичних творів, так і в доборі концертного репертуару. Такі ж принципи він сповідував і як викладач кафедри (зараз, як викладач Херсонського музичного училища). Як сучасник, 
який довгі роки слухав гру і працював поряд 3 Андрієм Анатолійовичем, вважаю, що на його формування більше вплинули саме викладачі третьої генерації з їх поміркованими поглядами на деякі аспекти гри ніж «харківська баянна школа формату В. Я. Подгорного».

А. М. Стрілець є носієм досвіду «харківської баянної школи», але під впливом своєї творчої і концертної діяльності (диригент міського театру народної музики «Обереги», головний диригент «Великого академічного Слобожанського ансамблю пісні і танцю», керівник оркестру народних інструментів Харківського вищого коледжу мистецтв) впроваджує в своєму класі нові риси та тенденції до музичного світогляду виконавця на баяні. Його вирізняє оркестрове мислення, прискіплива увага до структури музичних побудов, спрямування на роботу зі слухачем, виразність та емоційно образна наповненість виконання, як творів в цілому, так і найменших музичних епізодів. Стрілець А. М. створив кілька ансамблів, до складу яких окрім баяністів входять виконавці з числа студентів інших кафедр оркестрового факультету - струнно-смичкової та духової. Андрій Миколайович веде активний пошук нових форматів застосування баяну, нових тембральних сполучень і стилістичних напрямків. Останні роки, підтверджуючи сталу традицію харківської школи, активно займається композиторською діяльністю - створює новий музичний репертуар для баяна, ансамблів за участю баяна, оркестру народних інструментів, хорові твори.

До останньої, $\boldsymbol{n}$ 'ятої «генерації» викладачів-баяністів, входять Дмитро Жаріков (1986 р.н. клас професора О. В. Міщенка) та Юрій Дяченко (1986 р.н. клас професора О. І. Назаренка), які працюють на кафедрі з 2015 року. Ю. С. Дяченко - молодий виконавець, лауреат міжнародного конкурсу, диригент оркестрів народних інструментів. Він активно займається науковою діяльністю: у 2017 році захистив дисертацію та отримав звання кандидат мистецтвознавства. На кафедрі Юрій Станіславович викладає курс «Диригування» (він $є$ другим диригентом оркестру народних інструментів ХНУМ) і часто приймає участь в концертних заходах, як диригент, виконавець i ансамбліст.

Д. В. Жаріков є солістом Харківської обласної філармонії. Поки 
що рано робити висновки щодо особливостей його роботи в якості викладача. Але певні відмінності виконавського стилю Дмитра, концертуючого соліста-баяніста, вже помітні. І це не дивно. Д. Жаріков $\epsilon$ випускником не тільки ХНУМ ім. І. П. Котляревського як студент і асистент-стажист. Окрім цього, він закінчив асистентуру-стажування при Ростовській академії музики ім. С. В. Рахманінова під керуванням всесвітньовідомого баяніста Юрія Шишкіна, заслуженого артиста Росії. В свою чергу Ю. Шишкін - випускник класу метра педагогіки і композиції В. Семенова - $є$ помітною фігурою у баянному виконавстві: цей митець ствердив нові власні стандарти у створенні транскрипцій і виконанні цілого пласта музики для симфонічного оркестру. Його манера вирізняється надзвичайною пластичністю фразування за допомогою «активного міху», рельєфністю i наповненістю образної сфери, пошуком і відтворенням нових «позабаянних» тембрів, прискіпливою увагою до технології артикуляції. Потужний вплив Ю. Шишкіна певним чином відбився на музичному світогляді виконавця Жарікова. Слухаючи гру Дмитра, який дає десятки сольних концертів за рік, розумієш: він продовжує пошук власного стилю в багатовекторній системі координат, сформованих зусиллями кількох баянних шкіл. С підстави стверджувати, що процес змін у сталих традиціях харківської регіональної виконавської школи гри на баяні, є невпинним. Це, насамперед, пов'язано з наступними чинниками:

- зміна поколінь виконавців і викладачів, чий загальнолюдський $\mathrm{i}$ мистецький світогляди формувалися в різних історичних умовах, на базі дещо відмінних еталонів світосприйняття в усіх сферах буття людини;

- генеза виконавської школи через появу нових генерацій викладачів - носіїв унікальної інформації, успадкованої від своїх педагогів і помноженої на властивості творчої особистості;

- поступове привнесення кращих надбань інших регіональних шкіл через постійне спілкування, взаємозбагачення досвідом та навчання окремих представників у вищих мистецьких навчальних закладах інших територіальних центрів баянного виконавства;

- нівелювання рис, притаманних конкретній школі, що пов’язані 3 певними перебільшеннями значення окремих виконавських аспектів; 
- процес самоаналізу у лавах самих виконавців і викладачів, спричинений спілкуванням 3 широким колом музичної спільноти не пов'язаної з баяном;

- технологічні прориви в області глобального спілкування та загальнодоступності інформаційного простору для отримання будьяких музичних надбань людства.

Не зважаючи на зміну поколінь, риси Харківської баянної школи залишаються сталими і пізнаваними.

Нові тенденції в виконавстві на баяні. Головним трендом сучасного виконавства на баяні $є$ відхід від універсальності. Якщо поглянути на репертуар виконавців 20-50 річної давнини, то ми побачимо, що вони грали твори різних стильових напрямків, оригінальну музику і перекладення, академічний репертуар і народний, виступали як солісти і у складі ансамблів; часто виконували функцію концертмейстерів - були універсальними виконавцями. Зараз таких одиниці. В лавах сучасних баяністів відбувається помітне розшарування спеціалізації на історично усталених напрямках виконавства, як: академічне; естрадне; концертмейстерське; ансамблеве (з'являється багато виконавців на баяні, які спрямовують свої зусилля суто на грі в ансамблі та ще й певного складу).

Тенденція на уніфікацію виконавців відповідно до стилістичних напрямків музики, які вони обрали для власного самовираження $€$ загальноприйнятим фактом. Майже всі авторитетні міжнародні і національні конкурси мають не тільки вікові категорії, а й категорії для виконавців окремих стилів. Навіть в ансамблевих категоріях $€$ розподілення щодо складу і напрямку в музиці. Напрямок «Легкої музики» теж не є монолітним по суті. В ньому присутні: «вар'єте» (легка музика), джаз, рок. Інструмент є достатньо «модним», тому дуже часто баян або акордеон входить до складу рок-груп або інших естрадних колективів.

Спираючись на 20-річний досвід роботи на кафедрі народних інструментів ХНУМ, можу стверджувати, що і в Харківській регіональній баянній школі вже склалися передумови до розподілу студентів на певні виконавські напрямки ще під час навчання. Але це питання окремого дослідження.

Висновки. Багатотембровий готово-виборний баян, 
розвиваючись в площині професійного інструментального виконавства, в своїй генезі повторює шлях інших визнаних академічних музичних інструментів, наприклад, фортепіано. Широке та різнопланове коло застосування інструменту, загальносвітове розповсюдження свідчить про його зрілість, довершеність і належність до еліти музичного інструментарію світу.

Тенденції розвитку сучасного баяна на прикладі харківської регіональної виконавської школи за всіма критеріями повністю відповідають усталеним європейським стандартам. Спрощення комунікації за допомогою всесвітніх інтернет мереж, відкриття кордонів, скорочення часу на пересування конкретних виконавців до самих віддалених куточків світу через розгалужені транспортні магістралі, з одного боку, рівень розвитку виконавства на баяні (популярність, довершеність конструкції, великий обсяг оригінального репертуару, наявність великої кількості регіональних педагогічних центрів, загальносвітова ідентифікація), з іншого - дають підстави стверджувати, що баян (як академічний інструмент) і харківська регіональна школа гри на баяні, як один з провідних центрів розвитку баянного виконавства в Україні, є складовою світового мистецького простору. Її розвиток і підвищення авторитету пов’язані з: 1) подальшою інтеграцією до розгалуженої мережі вищих музичноосвітніх навчальних закладів, перш за все європейських; 2) прямим обміном досвідом як на рівні методики викладання та педагогічного репертуару, так і через впровадження програм по обміну студентами 3 провідними вишами Свропи і США; 3) постійним удосконаленням умов для підготовки фахівців певної уніфікації відповідно до загально прийнятих жанрово-стилістичних напрямків сучасного виконавства на баяні (акордеоні);

4) спрямованням на розкриття і реалізацію всіх конструктивних можливостей сучасних, удосконалених інструментів в площині прийомів звуковидобування, артикуляції і штрихів, тембральної колористики; 5) пошуком виконавських форм синтезу баяна (як академічного інструмента) і усталених форм академічних ансамблів - на кшталт струнних або духових оркестрів різного складу, театральних і вокально-хореографічних постановок, музично-світлових шоу і таке інше. 
Перспективи подальшого розвитку. Типологічний підхід вивчення досвіду генези харківської баянної школи може слугувати прикладом до наслідування під час розгляду досягнень більш молодих центрів розвитку виконавства на баяні (акордеоні), що нещодавно виникли та продовжують виникати на азійському континенті та у Південній Америці.

\section{Литература}

1. Давидов М. А.Історія виконавства на народних інструментах (Українська академічна школа) : підручник для вищих навчальних закладів. Київ, НМАУ ім. П. І. Чайковського 2002.

2. Имханицкий М. Что такое баян как украинский народный инструмент? Народно-інструментальне мистецтво на зламі XX-XXI століть : зб. матеріалів міжнародної науково-практичної конференції. Дрогобич. : Посвіт., 2007. С. 136-147.

3. Мирек А.М. Гармоника: прошлое и настоящее. М., 1994.

4. Свєтов А. Харківська баянна школа та ії видатні представники. Проблеми взаємодії мистецтва, педагогіки та теорії і практики освіти : зб. наукових праць ХДУМ ім. І. П. Котляревського. Харків, 2009. Вип. 25. С. 90-99.

5. Семешко А. Баянно-акордеонне мистецтво України на зламі XX-XXI століть : довідник. Тернопіль : Богдан, 2009. 244 с.

6. Снєдков I.I. Харківська школа баянно-акордеонного мистецтва: генеза становлення та кращі імена : навчальний посібник для мистецьких вишів. Харків 2016. $68 \mathrm{c}$.

7. Сташевський А. Великі жанри в українській музиці для баяна та акордеона. Тенденції розвитку в останні чверті XX на початку XXI ст. Луганськ : Поліграфресурс, 2007. 158 с.

8. Сташевський А. Українська оригінальна баянно-акордеонна література (до аналізу процесу еволюції). Проблеми історії й теорії академічного народноінструментального виконавства : матеріали Всеукраїнської науковопрактичної конференції до 80-річчя від дня народження М. А. Давидова. Луцьк : ВАТ «Волинська обласна друкарня», 2010. С. 119-129.

\section{Референс}

1. Imkhanycjkyj M. (2007) Chto takoe bajan kak ukraynskyj narodnyj ynstrument? [What is the chromatic button accordion as an Ukrainian folk instrument?] Proceedings of the Folk and instrumental art at the turn of the XX-XXI centuries : a collection of materials of the international scientific and practical conference, 
Drohobych : Posvit, pp.136-147.

2. Myrek A. M. (1994) Gharmonyka: proshloe y nastojashhee [Harmony: Past and Present]. Moskow: Myzuka. (In Russian).

3. Svjetov A. (2009) Kharkivsjka bajanna shkola ta jiji vydatni predstavnyky. [Kharkiv chromatic button accordion school and its representatives] Proceedings of the Problems of the interaction of art, pedagogy and the theory and practice of education: a collection of the scientific works of KNKUA, Kharkiv: Sovremennaja pechat, vol. 2, pp. 90-99.

4. Stashevsjkyj A. (2007) Velyki zhanry v ukrajinsjkij muzyci dlja bajana ta akordeona. Tendenciji rozvytku v ostanni chverti XX na pochatku XXI st. [Ladgescale genre in Ukrainian music for chromatic button accordion and accordion. Tendencies of the development in the last quarter of the twentieth century - at the beginning of the twenty-first century]. Lughansjk : Polighrafresurs. (In Ukrainian). 5. Stashevsjkyj A. Ukrajinsjka oryghinaljna bajanno-akordeonna literatura (do analizu procesu evoljuciji). [Ukrainian original chromatic button accordion literature (to the analysis of the evolution process)]. Proceedings of the Problems of history and theory of academic folk and instrumental performances: materials of the AllUkrainian scientific and practical conference to the 80th anniversary of M. A. Davydov birth. Lucjk : VAT «Volynsjka oblasna drukarnja», pp. 119-129. 